\title{
Kinetics and Mechanism of the Anilinolysis of Diethyl Thiophosphinic Chloride in Acetonitrile
}

\author{
Md. Ehtesham Ul Hoque and Hai Whang Lee* \\ Department of Chemistry, Inha University, Incheon 402-751, Korea. *E-mail: hwlee@inha.ac.kr \\ Received May 13, 2011, Accepted May 24, 2011
}

\begin{abstract}
The nucleophilic substitution reactions of diethyl thiophosphinic chloride with substituted anilines $\left(\mathrm{XC}_{6} \mathrm{H}_{4} \mathrm{NH}_{2}\right)$ and deuterated anilines $\left(\mathrm{XC}_{6} \mathrm{H}_{4} \mathrm{ND}_{2}\right)$ are investigated kinetically in acetonitrile at $55.0{ }^{\circ} \mathrm{C}$. The values of deuterium kinetic isotope effects (DKIEs; $\left.k_{\mathrm{H}} / k_{\mathrm{D}}\right)$ invariably increase from secondary inverse $\left(k_{\mathrm{H}} / k_{\mathrm{D}}<1\right)$ to primary normal $\left(k_{\mathrm{H}} / k_{\mathrm{D}}>1\right)$ as the nucleophiles change from the strongly basic to weakly basic anilines. The secondary inverse with the strongly basic anilines and primary normal DKIEs with the weakly basic anilines are rationalized by the gradual transition state (TS) variation from a predominant backside attack, via invariably increasing the fraction of a frontside attack, to a predominant frontside attack, in which the reaction mechanism is a concerted $\mathrm{S}_{\mathrm{N}} 2$ pathway. A frontside attack involving a hydrogen bonded, four-center-type TS is substantiated by the primary normal DKIEs.
\end{abstract}

Key Words : Phosphoryl transfer reaction, Anilinolysis, Diethyl thiophosphinic chloride, Deuterium kinetic isotope effect

\section{Introduction}

Phosphoryl and thiophosphoryl transfer reactions have been studied extensively because of an important class of reaction regarding biological chemistry and usefulness of synthesis. The authors investigated various types of phosphoryl and thiophosphoryl transfer reactions experimentally (anilinolysis, ${ }^{1}$ pyridinolysis, ${ }^{2}$ and benzylaminolysis ${ }^{3}$ ) and theoretically. ${ }^{4}$ In the present work, the nucleophilic substitution reactions of diethyl thiophosphinic chloride [2S; $\left.\mathrm{Et}_{2} \mathrm{P}(=\mathrm{S}) \mathrm{Cl}\right]$ with substituted anilines $\left(\mathrm{XC}_{6} \mathrm{H}_{4} \mathrm{NH}_{2}\right)$ and deuterated anilines $\left(\mathrm{XC}_{6} \mathrm{H}_{4} \mathrm{ND}_{2}\right)$ are investigated kinetically in acetonitrile at $55.0 \pm 0.1{ }^{\circ} \mathrm{C}$ (Scheme 1). The goal of this work is to gain further systematic information into the phosphoryl and thiophosphoryl transfer reactions, as well as to compare the reaction mechanism, stereoelectronic effects of the two ligands, and deuterium kinetic isotope effects (DKIEs; $k_{\mathrm{H}} / k_{\mathrm{D}}$ ) of the anilinolyses of dimethyl [1S; $\left.\mathrm{Me}_{2} \mathrm{P}(=\mathrm{S}) \mathrm{Cl}\right]^{1 \mathrm{j}}$ and diphenyl $\left[4 \mathrm{~S} ; \mathrm{Ph}_{2} \mathrm{P}(=\mathrm{S}) \mathrm{Cl}\right]^{1 \mathrm{e}}$ thiophosphinic chlorides. The kinetic results of the anilinolyses of their $\mathrm{P}=\mathrm{O}$ counterparts, dimethyl $\left[\mathbf{1 0} ; \mathrm{Me}_{2} \mathrm{P}(=\mathrm{O}) \mathrm{Cl}\right],{ }^{1 \mathrm{i}}$ diethyl [2O; $\left.\mathrm{Et}_{2} \mathrm{P}(=\mathrm{O}) \mathrm{Cl}\right],{ }^{11}$ methyl phenyl [3O; $\left.\mathrm{MePhP}(=\mathrm{O}) \mathrm{Cl}\right],{ }^{1 \mathrm{i}}$ and diphenyl $\left[40 ; \mathrm{Ph}_{2} \mathrm{P}(=\mathrm{O}) \mathrm{Cl}\right]^{1 \mathrm{~d}}$ phosphinic chlorides in $\mathrm{MeCN}$ are also discussed, together with those (solvolyses and anilinolyses) of the three phosphinates, dimethyl $[\mathbf{1 Z}$;

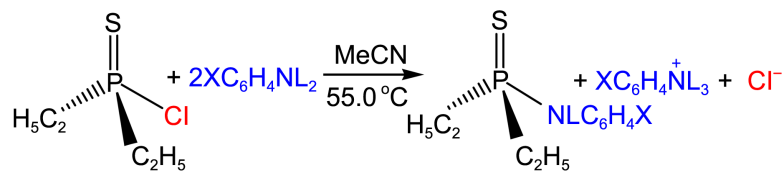

$$
\begin{aligned}
& \mathrm{L}=\mathrm{H} \text { or } \mathrm{D} \\
& \mathrm{X}=4-\mathrm{MeO}, 4-\mathrm{Me}, 3-\mathrm{Me}, \mathrm{H}, 4-\mathrm{F}, 4-\mathrm{Cl}, 3-\mathrm{Cl}
\end{aligned}
$$

Scheme 1. The studied reaction system.
$\mathrm{Me}_{2} \mathrm{P}(=\mathrm{O}) \mathrm{OC}_{6} \mathrm{H}_{4} \mathrm{Z}$ ], methyl phenyl [3Z; $\left.\mathrm{MePhP}(=\mathrm{O}) \mathrm{OC}_{6} \mathrm{H}_{4} \mathrm{Z}\right]$, and diphenyl $\left[4 \mathbf{Z} ; \mathrm{Ph}_{2} \mathrm{P}(=\mathrm{O}) \mathrm{OC}_{6} \mathrm{H}_{4} \mathrm{Z}\right]$ phosphinates. ${ }^{1 \mathrm{~m}}$ The sequence of the substrate number follows the size of the two ligands, $\mathrm{R}_{1}$ and $\mathrm{R}_{2}$, as follows: number of the substrate $\left(\mathrm{R}_{1}, \mathrm{R}_{2}\right)$; 1S, 10, and $1 \mathrm{Z}$ (Me,Me), 2S and 20 (Et,Et), 30 and $\mathbf{3 Z}$ $(\mathrm{Me}, \mathrm{Ph})$, and 4S, 4O, and $\mathbf{4 Z}(\mathrm{Ph}, \mathrm{Ph})$.

\section{Results and Discussion}

The observed pseudo-first-order rate constants $\left(k_{\mathrm{obsd}}\right)$ were found to follow eq. (1) for all of the reactions under pseudofirst-order conditions with a large excess of aniline nucleophile. The $k_{0}$ values were negligible $\left(k_{0}=0\right)$ in $\mathrm{MeCN}$. The second-order rate constants $\left(k_{\mathrm{H}(\mathrm{D})}\right)$ were determined for at least five concentrations of anilines. The linear plots of eq. (1) suggest that there is no base-catalysis or noticeable side reactions and that the overall reaction is described by Scheme 1.

$$
k_{\text {obsd }}=k_{0}+k_{\mathrm{H}(\mathrm{D})}\left[\mathrm{XC}_{6} \mathrm{H}_{4} \mathrm{NH}_{2}\left(\mathrm{D}_{2}\right)\right]
$$

The $k_{\mathrm{H}}$ and $k_{\mathrm{D}}$ values are summarized in Table 1 , together with the DKIEs $\left(k_{\mathrm{H}} / k_{\mathrm{D}}\right)$ and the Hammett $\rho_{\mathrm{X}}$ and Brönsted $\beta_{\mathrm{X}}$ coefficients. The $\mathrm{p} K_{\mathrm{a}}$ values of the anilines in water are used to obtain the Brönsted $\beta_{\mathrm{X}}$ values in $\mathrm{MeCN}$, and this procedure was justified experimentally and theoretically. ${ }^{5}$ The $\mathrm{p} K_{\mathrm{a}}$ and $\sigma$ values of the deuterated anilines are assumed to be identical to those of the anilines. The $\mathrm{p} K_{\mathrm{a}}$ value of deuterated X-aniline may be slightly greater than that of Xaniline, however, the difference is too small to be taken into account. ${ }^{6}$ Figures 1 and 2 show the Hammett $\left(\log k_{2} v s \sigma_{\mathrm{X}}\right)$ and Brönsted [log $k_{2}$ vs $\left.\mathrm{p} K_{\mathrm{a}}(\mathrm{X})\right]$ plots, respectively. The stronger nucleophile leads to the faster rate as observed in a typical nucleophilic substitution reaction. The magnitudes of the $\rho_{\mathrm{X}}$ and $\sigma_{\mathrm{X}}$ values of the reactions of $\mathbf{2 S}$ with the 
Table 1. The Second-Order Rate Constants $\left(k_{\mathrm{H}(\mathrm{D})} \times 10^{4} / \mathrm{M}^{-1} \mathrm{~s}^{-1}\right)$, Selectivity Parameters $\left(\rho_{\mathrm{X}}\right.$ and $\left.\beta_{\mathrm{X}}\right),{ }^{a}$ and DKIEs $\left(k_{\mathrm{H}} / k_{\mathrm{D}}\right)$ of the Reactions of $2 \mathrm{~S}$ (Diethyl Thiophosphinic Chloride) with $\mathrm{XC}_{6} \mathrm{H}_{4} \mathrm{NH}_{2}\left(\mathrm{D}_{2}\right)$ in $\mathrm{MeCN}$ at $55.0^{\circ} \mathrm{C}$

\begin{tabular}{cccc}
\hline $\mathrm{X}$ & $k_{\mathrm{H}} \times 10^{4} / \mathrm{M}^{-1} \mathrm{~s}^{-1}$ & $k_{\mathrm{D}} \times 10^{4} / \mathrm{M}^{-1} \mathrm{~s}^{-1}$ & $k_{\mathrm{H}} / k_{\mathrm{D}}$ \\
\hline $4-\mathrm{MeO}$ & $28.2 \pm 0.3^{b}$ & $31.4 \pm 0.2$ & $0.898 \pm 0.011^{i}$ \\
$4-\mathrm{Me}$ & $12.5 \pm 0.1$ & $13.2 \pm 0.1$ & $0.947 \pm 0.010$ \\
$3-\mathrm{Me}$ & $5.28 \pm 0.05$ & $5.38 \pm 0.03$ & $0.981 \pm 0.011$ \\
$\mathrm{H}$ & $3.30 \pm 0.03$ & $2.79 \pm 0.03$ & $1.18 \pm 0.02$ \\
$4-\mathrm{F}$ & $3.12 \pm 0.03$ & $2.46 \pm 0.02$ & $1.27 \pm 0.02$ \\
$4-\mathrm{Cl}$ & $0.702 \pm 0.006$ & $0.525 \pm 0.005$ & $1.34 \pm 0.02$ \\
$3-\mathrm{Cl}$ & $0.249 \pm 0.002$ & $0.182 \pm 0.002$ & $1.37 \pm 0.02$ \\
$-\rho_{\mathrm{X}}$ & $3.14 \pm 0.07^{c, d}$ & $3.46 \pm 0.05^{f, \mathrm{~g}}$ & \\
$\beta_{\mathrm{X}}$ & $1.12 \pm 0.06^{c, e}$ & $1.22 \pm 0.10^{f, h}$ & \\
\hline
\end{tabular}

${ }^{a}$ The $\sigma$ values were taken from Hansch, C.; Leo, A.; Taft, R. W. Chem. Rev. 1991, 91, 165. The $\mathrm{p} K_{\mathrm{a}}$ values of $\mathrm{X}$-anilines in water were taken from Streitwieser, A. Jr.; Heathcock, C. H.; Kosower, E. M. Introduction to Organic Chemistry, 4th ed.; Macmillan: New York, 1992; p 735. ${ }^{b}$ Standard deviation. ${ }^{c}$ Calculated from $k_{\mathrm{H}} \cdot{ }^{d}$ Correlation coefficient, $\mathrm{r}=$ 0.996. ${ }^{e} \mathrm{r}=0.996 .{ }^{f}$ Calculated from $k_{\mathrm{D}} .{ }{ }_{\mathrm{r}}=0.998 .{ }^{h_{\mathrm{r}}}=0.992 .{ }^{i}$ Standard error $\left\{=1 / k_{\mathrm{D}}\left[\left(\Delta k_{\mathrm{H}}\right)^{2}+\left(k_{\mathrm{H}} / k_{\mathrm{D}}\right)^{2} \times\left(\Delta k_{\mathrm{D}}\right)^{2}\right]^{1 / 2}\right\}$ from Crumpler, T. B.; Yoh, J. H. Chemical Computations and Errors; John Wiley: New York, 1940; p 178.

deuterated anilines are somewhat greater than those with the anilines, suggesting more sensitivity to substituent effects of the deuterated anilines compared to anilines, opposite to the other anilinolyses of phosphinic and thiophosphinic chlorides (see Table 2$)$. The values of DKIEs $\left(k_{\mathrm{H}} / k_{\mathrm{D}}\right)$ invariably increase from secondary inverse $\left(k_{\mathrm{H}} / k_{\mathrm{D}}<1\right)$ to primary normal $\left(k_{\mathrm{H}} / k_{\mathrm{D}}>1\right)$ as the nucleophiles change from the strongly to weakly basic anilines.

The second-order rate constants $\left(k_{\mathrm{H}}\right)$ with unsubstituted aniline at $55.0{ }^{\circ} \mathrm{C}$, summary of summations of inductive effects of the two ligands $\left[\Sigma \sigma_{\mathrm{I}}=\sigma_{\mathrm{I}}\left(\mathrm{R}_{1}\right)+\sigma_{\mathrm{I}}\left(\mathrm{R}_{2}\right)\right]{ }^{7}$ the natural bond order $(\mathrm{NBO})$ charges at the reaction center $\mathrm{P}$ atom in the gas phase [B3LYP/6-311+G(d,p) level of theory], ${ }^{8}$ summations of the Taft's steric constants of the two ligands $\left[\Sigma E_{\mathrm{S}}\right.$ $\left.=E_{\mathrm{S}}\left(\mathrm{R}_{1}\right)+E_{\mathrm{S}}\left(\mathrm{R}_{2}\right)\right],{ }^{9}$ Brönsted coefficient $\beta_{\mathrm{X}(\mathrm{H})}$ and $\beta_{\mathrm{X}(\mathrm{D})}$, and DKIEs $\left(k_{\mathrm{H}} / k_{\mathrm{D}}\right)$ of the reactions of $1 \mathrm{~S}, 2 \mathrm{~S}, 4 \mathrm{~S}(\mathrm{P}=\mathrm{S}$ systems $)$,

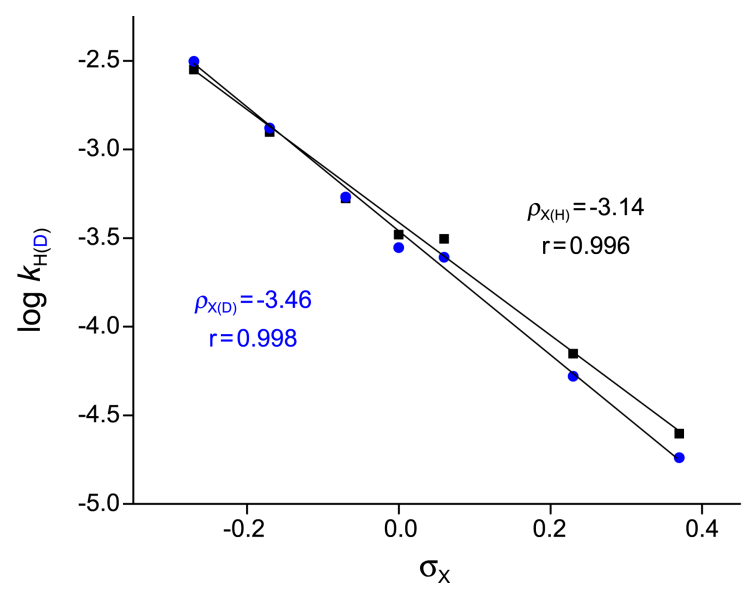

Figure 1. The Hammett plots $\left(\log k_{\mathrm{H}(\mathrm{D})} v s \sigma_{\mathrm{X}}\right)$ of the reactions of $2 S$ (diethyl thiophosphinic chloride) with $\mathrm{XC}_{6} \mathrm{H}_{4} \mathrm{NH}_{2}\left(\mathrm{D}_{2}\right)$ in $\mathrm{MeCN}$ at $55.0^{\circ} \mathrm{C}$.

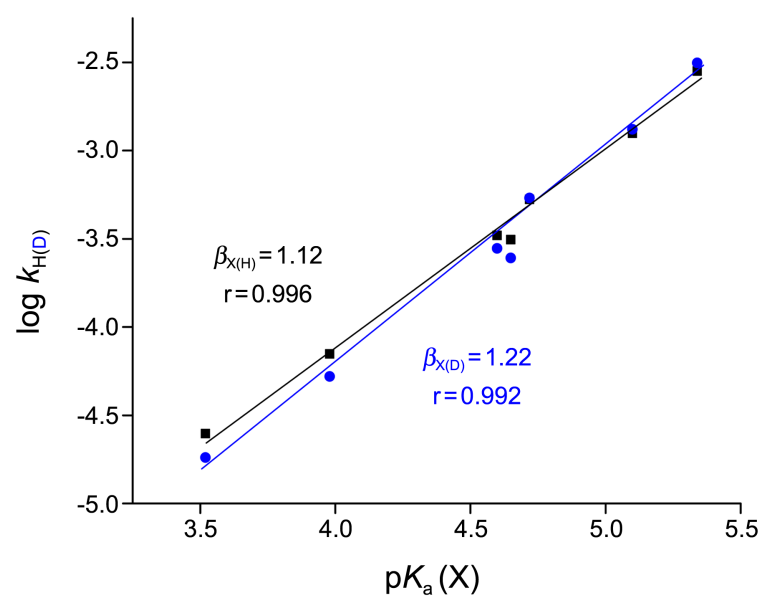

Figure 2. The Brönsted plots [log $\left.k_{\mathrm{H}(\mathrm{D})} v s \mathrm{p} K_{\mathrm{a}}(\mathrm{X})\right]$ of the reactions of $2 \mathrm{~S}$ (diethyl thiophosphinic chloride) with $\mathrm{XC}_{6} \mathrm{H}_{4} \mathrm{NH}_{2}\left(\mathrm{D}_{2}\right)$ in $\mathrm{MeCN}$ at $55.0^{\circ} \mathrm{C}$.

10, 2O, 3O, and $40(\mathrm{P}=\mathrm{O}$ counterparts $)$ with $\mathrm{XC}_{6} \mathrm{H}_{4} \mathrm{NH}_{2}\left(\mathrm{D}_{2}\right)$ in $\mathrm{MeCN}$ are summarized in Table 2 . The reactivity of the $\mathrm{P}=\mathrm{O}$ system is greater than that of its $\mathrm{P}=\mathrm{S}$ counterpart, $k_{\mathrm{H}}(\mathbf{1 O}) / k_{\mathrm{H}}(\mathbf{1 S})=799, k_{\mathrm{H}}(\mathbf{2 O}) / k_{\mathrm{H}}(\mathbf{2 S})=573$, and $k_{\mathrm{H}}(\mathbf{4 O}) / k_{\mathrm{H}}(\mathbf{4 S})$ $=2.9$. It is well known that the $\mathrm{P}=\mathrm{O}$ systems are generally more reactive than their $\mathrm{P}=\mathrm{S}$ counterparts for several reasons, the so-called 'thio effect', which is mainly the electronegativity difference between $\mathrm{O}$ and $\mathrm{S}$ and favors $\mathrm{O}$ over $\mathrm{S} .{ }^{10}$ The natural bond order $(\mathrm{NBO})$ charges of the reaction center $\mathrm{P}$ in the gas phase are $1.180(\mathbf{1 S}), 1.208(\mathbf{2 S})$, and $1.236(4 \mathrm{~S})(\mathrm{P}=\mathrm{S}$ system), and 1.793(10), 1.817(2O), 1.821(30), and 1.844(40) $(\mathrm{P}=\mathrm{O}$ system $)$ which are consistent with the inductive effects of $\mathrm{Ph}\left(\sigma_{\mathrm{I}}=+0.12\right)$, Et $\left(\sigma_{\mathrm{I}}=-0.01\right)$, and $\mathrm{Me}\left(\sigma_{\mathrm{I}}=-0.01\right)$ ligands. Solely considering the magnitudes of the positive charge of the reaction center $\mathrm{P}$ atom in the $\mathrm{P}=\mathrm{S}$ (and $\mathrm{P}=\mathrm{O}$ ) system, the sequence of the anilinolysis rates should be $\mathbf{1 S}<$ $\mathbf{2 S}<\mathbf{4 S}$ (and $\mathbf{1 0}<\mathbf{2 0}<\mathbf{3 0}<\mathbf{4 0}$ ). However, the observed sequence is $\mathbf{1 S}>>\mathbf{4 S}>\mathbf{2 S}$, giving relative rate ratio of 30(1S):1.8(4S): 1(2S) [and $10>>20>30>>40$, giving relative rate ratio of 4,520(10):109(20):80(30):1(40)]. These results are not in line with expectations from the inductive effects of the ligands, strongly suggesting that the inductive effects of the two ligands do not play any role to decide the reactivity of both the $\mathrm{P}=\mathrm{S}$ and $\mathrm{P}=\mathrm{O}$ systems.

Buncel and coworkers reported that the second-order rate constants for the ethanolyses of the three phosphinates, dimethyl $\left[\mathbf{1 Z} ; \mathrm{Me}_{2} \mathrm{P}(=\mathrm{O}) \mathrm{OC}_{6} \mathrm{H}_{4} \mathrm{Z}\right]$, methyl phenyl [3Z; $\left.\mathrm{MePhP}(=\mathrm{O}) \mathrm{OC}_{6} \mathrm{H}_{4} \mathrm{Z}\right]$, and diphenyl $\left[\mathbf{4 Z} ; \mathrm{Ph}_{2} \mathrm{P}(=\mathrm{O}) \mathrm{OC}_{6} \mathrm{H}_{4} \mathrm{Z}\right]$ phosphinates with $\mathrm{Z}=4-\mathrm{NO}_{2}$, gave relative rate ratio of $235\left(k_{\mathrm{EtO}^{-}}=230\right): 69\left(k_{\mathrm{EtO}^{-}}=67.6\right): 1\left(k_{\mathrm{EtO}^{-}}=0.980 \mathrm{M}^{-1} \mathrm{~s}^{-1}\right)$ in anhydrous ethanol at $25.0^{\circ} \mathrm{C}$, resulting in $\delta=0.478(\mathrm{r}=$ $0.953)$ according to the Taft' eq. $\left(\log k_{\mathrm{EtO}^{-}}=\delta \Sigma E_{\mathrm{S}}+\mathrm{C}\right) .{ }^{11}$ Williams and coworkers reported that the second-order rate constants for the phosphate catalyzed hydrolyses of the two phosphinates, $1 \mathrm{Z}$ and $\mathbf{4 Z}$ with $\mathrm{Z}=4-\mathrm{NO}_{2}$, gave relative rate ratio of $52\left(k_{\mathrm{HPO}_{4}}{ }^{2-}=1.06 \times 10^{-2}\right): 1\left(k_{\mathrm{HPO}_{4}}{ }^{2-}=2.05 \times 10^{-4} \mathrm{M}^{-1}\right.$ $\mathrm{s}^{-1}$ ) in $10 \%$ dioxane-aqueous $0.1 \mathrm{M} \mathrm{NaCl}$ at $25.0{ }^{\circ} \mathrm{C}$, resulting in $\delta=0.345 .^{12}$ The authors reported that the anilinolyses 
Table 2. The Summary of Second-Order Rate Constants $\left(k_{\mathrm{H}} \times 10^{3} / \mathrm{M}^{-1} \mathrm{~s}^{-1}\right)$ with $\mathrm{C}_{6} \mathrm{H}_{5} \mathrm{NH}_{2}$ at $55.0^{\circ} \mathrm{C}$, Summations of Inductive Effects of the Two Ligands $\left(\Sigma \sigma_{\mathrm{I}}\right)$, NBO Charges at Reaction Center P, Summations of the Taft's Steric Constants of the Two Ligands $\left(\Sigma E_{\mathrm{S}}\right)$, $\beta_{\mathrm{X}(\mathrm{H} \text { and } \mathrm{D}) \text {, and }}$ $k_{\mathrm{H}} / k_{\mathrm{D}}$ Values of the Reactions of $1 \mathrm{~S}, 2 \mathrm{~S}, 4 \mathrm{~S}, 10,2 \mathrm{O}, 3 \mathrm{O}$ and 40 with $\mathrm{XC}_{6} \mathrm{H}_{4} \mathrm{NH}_{2}\left(\mathrm{D}_{2}\right)$ in $\mathrm{MeCN}$

\begin{tabular}{|c|c|c|c|c|c|c|c|}
\hline Substrate & $k_{\mathrm{H}} \times 10^{3 a}$ & $\Sigma \sigma_{\mathrm{I}}$ & charge at $P$ & $-\Sigma E_{\mathrm{S}}$ & $\beta_{\mathrm{X}(\mathrm{H})} / \beta_{\mathrm{X}(\mathrm{D})}$ & $k_{\mathrm{H}} / k_{\mathrm{D}}$ & ref \\
\hline 1S; $\mathrm{Me}_{2} \mathrm{P}(=\mathrm{S}) \mathrm{Cl}$ & 9.79 & -0.02 & 1.180 & 0.00 & $1.28 / 1.22^{b}$ & $0.74-0.95^{b}$ & $1 \mathrm{j}$ \\
\hline 2S; $\mathrm{Et}_{2} \mathrm{P}(=\mathrm{S}) \mathrm{Cl}$ & 0.330 & -0.02 & 1.208 & 0.14 & $1.12 / 1.22^{b}$ & $0.90-1.37^{b}$ & this work \\
\hline 4S; $\mathrm{Ph}_{2} \mathrm{P}(=\mathrm{S}) \mathrm{Cl}$ & 0.601 & 0.24 & 1.236 & 4.96 & $1.40 / 1.40^{b}$ & $1.00-1.10^{b}$ & $1 \mathrm{e}$ \\
\hline 10; $\mathrm{Me}_{2} \mathrm{P}(=\mathrm{O}) \mathrm{Cl}$ & $7,820^{c}$ & -0.02 & 1.793 & 0.00 & $1.62 / 1.56^{d}$ & $0.70-0.90^{d}$ & $1 \mathrm{i}$ \\
\hline 2O; $\mathrm{Et}_{2} \mathrm{P}(=\mathrm{O}) \mathrm{Cl}$ & $189^{e}$ & -0.02 & 1.817 & 0.14 & $0.56 / 0.52^{f}$ & $0.83-0.97^{f}$ & 11 \\
\hline 30; $\mathrm{MePhP}(=\mathrm{O}) \mathrm{Cl}$ & 138 & 0.11 & 1.821 & 2.48 & $0.88 / 0.81^{b}$ & $1.62-2.10^{b}$ & $1 \mathrm{i}$ \\
\hline 40; $\mathrm{Ph}_{2} \mathrm{P}(=\mathrm{O}) \mathrm{Cl}$ & 1.73 & 0.24 & 1.844 & 4.96 & $1.69 / 1.62^{b}$ & $1.42-1.82^{b}$ & $1 d$ \\
\hline
\end{tabular}

${ }^{a}$ Values with $\mathrm{C}_{6} \mathrm{H}_{5} \mathrm{NH}_{2}$ at $55.0^{\circ} \mathrm{C} .{ }^{b}$ Values at $55.0{ }^{\circ} \mathrm{C} .{ }^{c} \mathrm{The}$ value of $k_{\mathrm{H}}=7.82 \mathrm{M}^{-1} \mathrm{~s}^{-1}$ at $55.0^{\circ} \mathrm{C}$ was calculated by extrapolation in the Arrhenius plot $(\mathrm{r}=$ $0.999)$ with empirical kinetic data: $k_{\mathrm{H}}=0.776\left(0.0^{\circ} \mathrm{C}\right), 1.01\left(5.0{ }^{\circ} \mathrm{C}\right)$ and $1.61 \mathrm{M}^{-1} \mathrm{~s}^{-1}\left(15.0^{\circ} \mathrm{C}\right)$ from ref. 1 i. ${ }^{d}$ Values at $15.0^{\circ} \mathrm{C}$. ${ }^{e} \mathrm{The}$ value of $k_{\mathrm{H}}=189 \times$ $10^{-3} \mathrm{M}^{-1} \mathrm{~s}^{-1}$ at $55.0^{\circ} \mathrm{C}$ was obtained by extrapolation in the Arrhenius plot $(\mathrm{r}=0.999)$ with kinetic data: $k_{\mathrm{H}}=117\left(40.0^{\circ} \mathrm{C}\right), 162\left(50.0^{\circ} \mathrm{C}\right)$, and $211 \times 10^{-3}$ $\mathrm{M}^{-1} \mathrm{~s}^{-1}\left(60.0^{\circ} \mathrm{C}\right)$ from $11 .{ }^{\circ}$ Values at $50.0^{\circ} \mathrm{C}$.

$\left(\mathrm{C}_{6} \mathrm{H}_{5} \mathrm{NH}_{2}\right)$ of the three phosphinates, $\mathbf{1 Z}, \mathbf{3 Z}$, and $\mathbf{4 Z}$ with $\mathrm{Z}$ $=4-\mathrm{NO}_{2}$ in DMSO at $60.0{ }^{\circ} \mathrm{C}$ gave a small value of $\delta=$ $0.021(\mathrm{r}=0.954) .{ }^{1 \mathrm{~m}}$ It is evident that the sequence of the anilinolysis rates of the phosphinic chlorides, $\mathbf{1 0}>\mathbf{2 0}>$ $30>40$, is inversely proportional to the sizes of the two ligands; $\mathrm{Ph}, \mathrm{Ph}($ 4O) $>\mathrm{Me}, \mathrm{Ph}(\mathbf{3 O})>\mathrm{Et}, \mathrm{Et}(\mathbf{2 O})>\mathrm{Me}, \mathrm{Me}$ (10). The plots of $\log k_{\mathrm{H}}$ against $\Sigma E_{\mathrm{S}}$ for the reactions of three phosphinic chlorides $\left(\mathbf{1 0}, \mathbf{3 0}\right.$, and 4O) with $\mathrm{C}_{6} \mathrm{H}_{5} \mathrm{NH}_{2}$ in $\mathrm{MeCN}$ at $55.0^{\circ} \mathrm{C}$ gave the great sensitivity coefficient of the steric effects of $\delta=0.737\left(\mathrm{r}=0.999\right.$; good linearity). ${ }^{1 \mathrm{i}}$ The anilinolysis rates of four phosphinic chlorides (10, 20, 30, and 40) with $\mathrm{C}_{6} \mathrm{H}_{5} \mathrm{NH}_{2}$ in $\mathrm{MeCN}$ at $55.0{ }^{\circ} \mathrm{C}$ gave a value of $\delta=0.572$ ( $\mathrm{r}=0.895$; roughly linear), due to a large negative deviation of $\mathbf{2 0}$ from the slope of $\delta=0.737 .{ }^{11}$ These results indicate that the relative reactivities of the phosphinates and phosphinic chlorides are predominantly dependent on steric effects over the inductive effects of the ligands.

In the $\mathrm{P}=\mathrm{O}$ system, the sequence of the anilinolysis rates ( $k_{\mathrm{H}}$ with $\mathrm{C}_{6} \mathrm{H}_{5} \mathrm{NH}_{2}$ in $\mathrm{MeCN}$ at $55.0^{\circ} \mathrm{C}$ ) of the $\mathrm{R}_{1} \mathrm{R}_{2}(\mathrm{P}=\mathrm{O}) \mathrm{Cl}-$ type substrates, studied in this lab, is as follows: $\mathrm{R}_{1}, \mathrm{R}_{2}\left(k_{\mathrm{H}} \times\right.$ $\left.10^{3} / \mathrm{M}^{-1} \mathrm{~s}^{-1}\right) ; \operatorname{Me}, \operatorname{Me}(10 ; 7,820)^{1 \mathrm{j}}>\operatorname{Et}, \operatorname{Et}(2 \mathrm{O} ; 189)^{11}>$ $\mathrm{Me}, \mathrm{Ph}(3 \mathbf{3 O} ; 138)^{1 \mathrm{i}}>\mathrm{MeO}, \mathrm{MeO}(4.28)^{1 \mathrm{~g}}>\operatorname{EtO}, \operatorname{EtO}(2.82)^{1 \mathrm{~g}}>$ $\mathrm{EtO}, \mathrm{PhO}(2.00)^{1 \mathrm{f}}>\mathrm{Ph}, \mathrm{Ph}(40 ; 1.73)^{1 \mathrm{~d}}>\mathrm{PhO}, \mathrm{PhO}(0.891)^{1 \mathrm{a}}>$ cHex,cHex(0.00940). ${ }^{1 \mathrm{n}}$ Dividing the studied substrates into two groups, $a$ o-group with $\mathrm{R}_{1}=\mathrm{R}_{2}=$ alkyl and/or phenyl and bo-group with $\mathrm{R}_{1}=\mathrm{R}_{2}=$ alkoxy and/or phenoxy, the sequence of the rates is as follows: ao-group; $\operatorname{Me}, \operatorname{Me}(\mathbf{1 0} ; 7,820)^{1 \mathrm{j}}>$ $\operatorname{Et}, \operatorname{Et}(20 ; 189)^{11}>\operatorname{Me}, \operatorname{Ph}(\mathbf{3 O} ; 138)^{1 \mathrm{i}}>\operatorname{Ph}, \operatorname{Ph}(40 ; 1.73),{ }^{1 \mathrm{~d}}$ and bo-group; $\mathrm{MeO}, \mathrm{MeO}(4.28)^{1 \mathrm{~g}}>\mathrm{EtO}, \mathrm{EtO}(2.82)^{1 \mathrm{~g}}>$ $\mathrm{EtO}, \mathrm{PhO}(2.00)^{1 \mathrm{f}}>\mathrm{PhO}, \mathrm{PhO}(0.891){ }^{1 \mathrm{a}}$ It is clear that the anilinolysis rate of both groups becomes slower as the size of the two ligands becomes greater. Herein, the anilinolysis rate of dicyclohexyl phosphinic chloride $\left[\mathrm{cHex}_{2} \mathrm{P}(=\mathrm{O}) \mathrm{Cl}\right]$ is too slow to be rationalized by the stereoelectronic effects of the two ligands. ${ }^{1 \mathrm{n}}$

In the $\mathrm{P}=\mathrm{S}$ system, the sequence of the anilinolysis rates $\left(k_{\mathrm{H}}\right.$ with $\mathrm{C}_{6} \mathrm{H}_{5} \mathrm{NH}_{2}$ in $\mathrm{MeCN}$ at $55.0{ }^{\circ} \mathrm{C}$ ) of the $\mathrm{R}_{1} \mathrm{R}_{2}(\mathrm{P}=\mathrm{S}) \mathrm{Cl}-$ type substrates, studied in this lab, is as follows: $\mathrm{R}_{1}, \mathrm{R}_{2}$ $\left(k_{\mathrm{H}} \times 10^{3} / \mathrm{M}^{-1} \mathrm{~s}^{-1}\right) ; \operatorname{Me}, \operatorname{Me}(\mathbf{1 S} ; 9.79)^{1 \mathrm{j}}>\operatorname{Me}, \operatorname{PhO}(7.25)^{1 \mathrm{k}}>$ $\mathrm{MeO}, \mathrm{MeO}(1.09)^{1 \mathrm{~g}}>\mathrm{Ph}, \mathrm{Ph}(\mathbf{4 S} ; 0.601)^{1 \mathrm{e}}>\operatorname{EtO}, \mathrm{EtO}(0.512)^{1 \mathrm{~g}}$
$>$ Et,Et(2S; 0.330) $>$ EtO, $\operatorname{PhO}(0.280)^{1 \mathrm{f}}>\mathrm{Ph}, \mathrm{PhS}(0.175)^{\mathrm{lh}}>$ $\mathrm{PhO}, \mathrm{PhO}(0.101) .{ }^{1 \mathrm{c}}$ Dividing the studied substrates into two groups, $a$ s-group with $\mathrm{R}_{1}=\mathrm{R}_{2}=$ alkyl and/or phenyl and $b$ sgroup with $\mathrm{R}_{1}=\mathrm{R}_{2}=$ alkoxy and/or phenoxy, the sequence of the rates is as follows: as-group; $\operatorname{Me}, \operatorname{Me}(\mathbf{1 S} ; 9.79)^{1 \mathrm{j}}$ $>\mathrm{Ph}, \mathrm{Ph}(\mathbf{4 S} ; 0.601)^{1 \mathrm{e}}>\operatorname{Et}, \operatorname{Et}(\mathbf{2 S} ; 0.330)$, and $b$ s-group; $\mathrm{MeO}, \mathrm{MeO}(1.09)^{1 \mathrm{~g}}>\mathrm{EtO}, \mathrm{EtO}(0.512)^{1 \mathrm{~g}}>\mathrm{EtO}, \mathrm{PhO}(0.280)^{1 \mathrm{f}}$ $>\mathrm{PhO}, \mathrm{PhO}(0.101) .^{1 \mathrm{c}}$ The anilinolysis of $\mathrm{Y}-O$-aryl methyl phosphonochloridothioates $\left[\mathrm{Me}\left(\mathrm{YC}_{6} \mathrm{H}_{4} \mathrm{O}\right) \mathrm{P}(=\mathrm{S}) \mathrm{Cl}\right]$ in $\mathrm{MeCN}$ exhibited biphasic concave downwards for substituent $\mathrm{X}$ variations in the nucleophiles with a break region ${ }^{13}$ and the DKIEs were primary normal $\left(k_{\mathrm{H}} / k_{\mathrm{D}}=1.03-1.30\right)$ for stronger nucleophiles and unprecedented large secondary inverse $\left(k_{\mathrm{H}} /\right.$ $\left.k_{\mathrm{D}}=0.367-0.567\right)^{14}$ for weaker nucleophiles. ${ }^{1 \mathrm{k}}$ In $b$ s-group, the rate becomes slower as the size of the two ligands becomes greater as in the $\mathrm{P}=\mathrm{O}$ system, while, in as-group, the rather faster rate of $\mathbf{4 S}$ (with two phenyl) than $2 \mathrm{~S}$ (with two ethyl) is surprising result. The authors conclude that the steric effects of the two ligands on the anilinolysis rate are predominant factor to decide the reactivities of the $\mathrm{P}=\mathrm{O}$ system with both $a \mathrm{o}-$ and $b$ o-groups and the $\mathrm{P}=\mathrm{S}$ system with $b$ s-group, while one of the major factors in the $\mathrm{P}=\mathrm{S}$ system with $a$ s-group.

The DKIEs are one of the strong tools to clarify the reaction mechanism. The DKIEs have provided a useful means to determine the TS structures in the nucleophilic substitution reactions, and how the reactants, especially through changes in substituents, alter the TS structures. ${ }^{15}$ Incorporation of deuterium in the nucleophile has an advantage in that the $\alpha$-DKIEs reflect only the degree of bond formation. When partial deprotonation of the aniline occurs in a rate-limiting step by hydrogen bonding, the $k_{\mathrm{H}} / k_{\mathrm{D}}$ values are greater than unity, primary normal $\left(k_{\mathrm{H}} / k_{\mathrm{D}}>1.0\right) .{ }^{16}$ The greater the extent of the hydrogen bond, the value of $k_{\mathrm{H}} / k_{\mathrm{D}}$ becomes greater. In contrast, the DKIEs can only be secondary inverse $\left(k_{\mathrm{H}} / k_{\mathrm{D}}<1.0\right)$ in a normal $\mathrm{S}_{\mathrm{N}} 2$ reaction, since the $\mathrm{N}-\mathrm{H}(\mathrm{D})$ vibrational frequencies invariably increase upon going to the TS because of an increase in steric congestion in the bond-making process. ${ }^{16}$ The greater the degree of the steric congestion in the TS, the value of $k_{\mathrm{H}} / k_{\mathrm{D}}$ becomes smaller. In general, the magnitude of $\beta_{\mathrm{X}}$ value represents the 
degree of bond formation, and the greater $\beta_{\mathrm{X}}$ value is treated as greater degree of bond formation. As seen in Table 2, however, there is no correlation between the magnitudes of $\beta_{\mathrm{X}}$ and $k_{\mathrm{H}} / k_{\mathrm{D}}$ values.

The DKIEs of $1 \mathrm{~S}\left(k_{\mathrm{H}} / k_{\mathrm{D}}=0.74-0.95\right),{ }^{1 \mathrm{j}} \mathbf{1 0}\left(k_{\mathrm{H}} / k_{\mathrm{D}}=0.70\right.$ $0.90),{ }^{1 \mathrm{i}}$ and $2 \mathrm{O}\left(k_{\mathrm{H}} / k_{\mathrm{D}}=0.83-0.97\right)^{11}$ are secondary inverse, while those of $4 \mathrm{~S}\left(k_{\mathrm{H}} / k_{\mathrm{D}}=1.00-1.10\right),{ }^{\text {ee }} \mathbf{3 O}\left(k_{\mathrm{H}} / k_{\mathrm{D}}=1.62-\right.$ $2.10),{ }^{1 \mathrm{i}}$ and $\mathbf{4 O}\left(k_{\mathrm{H}} / k_{\mathrm{D}}=1.42-1.82\right)^{1 \mathrm{~d}}$ are primary normal. In the present work (2S), however, the DKIEs invariably change from secondary inverse $\left(k_{\mathrm{H}} / k_{\mathrm{D}}=0.898\right.$; min at $\left.\mathrm{X}=4-\mathrm{MeO}\right)$ to primary normal $\left(k_{\mathrm{H}} / k_{\mathrm{D}}=1.37\right.$; $\max$ at $\left.\mathrm{X}=3-\mathrm{Cl}\right)$ as the substituent $\mathrm{X}$ of the nucleophiles change from electrondonating to electron-withdrawing.

The attacking direction of aniline nucleophile can be semiquantitatively divided into three groups on the basis of the magnitudes of the $k_{\mathrm{H}} / k_{\mathrm{D}}$ values: (i) predominant backside attack TSb (Scheme 2) when $k_{\mathrm{H}} / k_{\mathrm{D}}<1$; (ii) the fraction of the frontside attack TSf (Scheme 2) is greater than that of backside attack TSb when $1.0<k_{\mathrm{H}} / k_{\mathrm{D}}<1.1$ : (iii) predominant frontside attack TSf when $k_{\mathrm{H}} / k_{\mathrm{D}}>1.1 .{ }^{17}$ The authors accordingly proposed that the anilinolyses of 1S, 10, and 20 proceed through a concerted mechanism involving predominant TSb on the basis of the secondary inverse DKIEs, since the two small ligands readily enable backside nucleophilic attack. On the contrary, a concerted mechanism involving predominant hydrogen-bonded four-center-type TSf was proposed for the anilinolyses of $\mathbf{3 0}$ and $\mathbf{4 0}$ on the basis of the considerably large primary normal DKIEs, since frontside attack is more favorable than backside attack due to the large sizes of the two ligands. Meanwhile, a concerted mechanism with both frontside TSf and backside attack TSb was proposed for the anilinolysis of $\mathbf{4 S}$, where the fraction of a frontside attack is greater than that of a backside attack on the basis of relatively small primary normal DKIEs. ${ }^{18}$

In the present work, thus, secondary inverse with the strongly basic anilines and primary normal DKIEs with the weakly basic anilines can be rationalized by the gradual TS variation from a predominant backside attack TSb, via invariably increasing the fraction of a frontside attack, to a predominant frontside attack TSf, in which the reaction mechanism is a concerted $\mathrm{S}_{\mathrm{N}} 2$ pathway. ${ }^{19}$ Both the anilinolyses of $\mathrm{P}=\mathrm{O}$ and $\mathrm{P}=\mathrm{S}$ systems, the proposed mechanism is generally a normal $\mathrm{S}_{\mathrm{N}} 2$ process because of good leaving group ability of $\mathrm{Cl}^{20}$ The nucleophilic attacking direction is correlated with the steric effects of the two ligands, $\mathrm{R}_{1}$ and $\mathrm{R}_{2}$. The larger the two ligands, the greater steric hindrance occurs, and a frontside attack becomes more favorable. In the $\mathrm{P}=\mathrm{O}$ system, a backside nucleophilic attack is favorable,

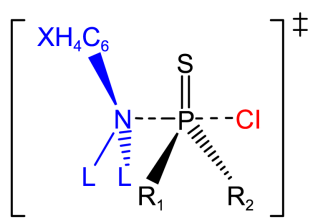

TSb

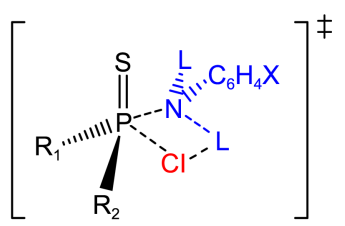

TSf
Scheme 2. Backside attack TSb and frontside attack TSf.
10 and 20, until the severe steric hindrance prohibits backside attack and consequently frontside attack becomes predominant, 30 and 40 . In the $\mathrm{P}=\mathrm{S}$ system, $\mathbf{1 S}$ favors a backside attack, $\mathbf{2 S}$ favors both backside and frontside attack, and 4S favors greater fraction of frontside attack than that of backside attack.

\section{Experimental Section}

Materials. HPLC-grade MeCN (water content is less than $0.005 \%$ ) was used for kinetic studies without further purification. Anilines were redistilled or recrystallized before use as previously described. ${ }^{1}$ Deuterated anilines were synthesized by heating anilines with deuterium oxide (99.9 atom \% D) and one drop of $\mathrm{HCl}$ catalyst at $90{ }^{\circ} \mathrm{C}$ for 72 hours, and after numerous attempts, anilines were deuterated more than $98 \%$, as confirmed by ${ }^{1} \mathrm{H}$ NMR. Diethyl thiophosphinic chloride was prepared by the following one step synthetic route. ${ }^{21}$ Chlorodiethyl phosphine $(97 \%)$ was stirred overnight with sulfur in THF. The solvent was removed under reduced pressure and a pale yellow liquid product was isolated through column chromatography $(15 \%$ ethyl acetate $+n$-hexane). Analytical and spectroscopic data of the product gave the following results:

$\left(\mathbf{C}_{2} \mathbf{H}_{5}\right)_{2} \mathbf{P}(=\mathbf{S}) \mathbf{C l}$ : Pale yellow liquid; ${ }^{1} \mathrm{H} \mathrm{NMR}(400 \mathrm{MHz}$, $\left.\mathrm{CDCl}_{3}\right) \delta 1.26-1.49\left(\mathrm{~m}, 6 \mathrm{H}, 2 \mathrm{CH}_{3}\right), 2.28-2.41(\mathrm{~m}, 4 \mathrm{H}, 2$ $\left.\mathrm{CH}_{2}\right) ;{ }^{13} \mathrm{C} \mathrm{NMR}\left(100 \mathrm{MHz}, \mathrm{CDCl}_{3}\right) \delta 6.92\left(\mathrm{CH}_{3}\right), 32.97$, $33.53\left(\mathrm{CH}_{2}\right) ;{ }^{31} \mathrm{P}$ NMR $\left(162 \mathrm{MHz}, \mathrm{CDCl}_{3}\right) \delta-132.97$ (s, 1P, $\mathrm{P}=\mathrm{S}) ; m / z, 156\left(\mathrm{M}^{+}\right)$.

Kinetics Measurement. Rates were measured conductometrically at $55.0{ }^{\circ} \mathrm{C}$ as previously described. ${ }^{1}$ [Substrate] $=$ $0.001 \mathrm{M}$ and [Nucleophile] $=(0.1-0.5) \mathrm{M}$ were used for the present work. Pseudo-first-order rate constant values were the average of three runs that were reproducible within $\pm 3 \%$.

Product Analysis. Diethyl thiophosphinic chloride was reacted with excess 4-methoxyaniline for more than 15 halflives at $55.0{ }^{\circ} \mathrm{C}$ in $\mathrm{MeCN}$. The 4-methoxy aniline hydrochloride salt was separated by filtration. Acetonitrile was removed under reduced pressure. The product was isolated with ether by a work-up process and dried over anhydrous $\mathrm{MgSO}_{4}$. After filtration the product was isolated by evaporating the solvent under reduced pressure. The Analytical and spectroscopic data of the product after column chromatography (silica gel $/ 30 \%$ ethyl acetate $+n$-hexane) gave the following results:

$\left(\mathbf{C}_{2} \mathbf{H}_{5}\right)_{2} \mathbf{P}(=\mathbf{S}) \mathbf{N H C}_{6} \mathbf{H}_{4}-4-\mathbf{O C H}_{3}$ : Dark-brown solid; mp (7980) ${ }^{\circ} \mathrm{C} ;{ }^{1} \mathrm{H}$ NMR $\left(400 \mathrm{MHz}, \mathrm{CDCl}_{3}\right) \delta 1.18-1.27(\mathrm{~m}, 6 \mathrm{H}$, $\left.2 \mathrm{CH}_{3}\right), 1.90-2.09\left(\mathrm{~m}, 4 \mathrm{H}, 2 \mathrm{CH}_{2}\right), 3.77\left(\mathrm{~s}, 3 \mathrm{H}, \mathrm{CH}_{3} \mathrm{O}\right), 4.13$ (s, 1H, NH), 6.81 (d, $J=6.8 \mathrm{~Hz}, 2 \mathrm{H}$, phenyl), 6.95 (d, 2H, $J$ $=8.8 \mathrm{~Hz}$, phenyl); ${ }^{13} \mathrm{C} \mathrm{NMR}\left(100 \mathrm{MHz}, \mathrm{CDCl}_{3}\right) \delta 6.28$ $\left(\mathrm{CH}_{3}\right), 25.39,26.03\left(\mathrm{CH}_{2}\right), 55.49\left(\mathrm{OCH}_{3}\right), 114.74,123.15$, 132.83, $156.08\left(\mathrm{C}=\mathrm{C}\right.$, aromatic); ${ }^{31} \mathrm{P} \mathrm{NMR}\left(162 \mathrm{MHz}, \mathrm{CDCl}_{3}\right)$ $\delta 80.18(\mathrm{~s}, 1 \mathrm{P}, \mathrm{P}=\mathrm{S}) ; m / z, 243\left(\mathrm{M}^{+}\right)$.

Acknowledgments. This work was supported by the Brain Korea 21 Program from National Research Founda- 
tion of Korea and Inha University Research Grant.

\section{References and Notes}

1. (a) Guha, A. K.; Lee, H. W.; Lee, I. J. Chem. Soc., Perkin Trans. 2 1999, 765. (b) Lee, H. W.; Guha, A. K.; Lee, I. Int. J. Chem. Kinet. 2002, 34, 632. (c) Hoque, M. E. U.; Dey, S.; Guha, A. K.; Kim, C. K.; Lee, B. S.; Lee, H. W. J. Org. Chem. 2007, 72, 5493. (d) Hoque, M. E. U.; Lee, H. W. Bull. Korean Chem. Soc. 2007, 28, 936. (e) Dey, N. K.; Han, I. S.; Lee, H. W. Bull. Korean Chem. Soc. 2007, 28, 2003. (f) Hoque, M. E. U.; Dey, N. K.; Kim, C. K.; Lee, B. S.; Lee, H. W. Org. Biomol. Chem. 2007, 5, 3944. (g) Dey, N. K.; Hoque, M. E. U.; Kim, C. K.; Lee, B. S.; Lee, H. W. J. Phys. Org. Chem. 2008, 21, 544. (h) Lumbiny, B. J.; Lee, H. W. Bull. Korean Chem. Soc. 2008, 29, 2065. (i) Dey, N. K.; Hoque, M. E. U.; Kim, C. K.; Lee, B. S.; Lee, H. W. J. Phys. Org. Chem. 2009, 22, 425. (j) Dey, N. K.; Kim, C. K.; Lee, H. W. Bull. Korean Chem. Soc. 2009, 30, 975. (k) Hoque, M. E. U.; Guha, A. K.; Kim, C. K.; Lee, B. S.; Lee, H. W. Org. Biomol. Chem. 2009, 7 , 2919. (1) Dey, N. K.; Lee, H. W. Bull. Korean Chem. Soc. 2010, 31, 1403. (m) Dey, N. K.; Kim, C. K.; Lee, H. W. Org. Biomol. Chem. 2011, 9, 717. (n) Hoque, M. E. U.; Lee, H. W. Bull. Korean Chem. Soc. 2011, 32, 1997.

2. (a) Guha, A. K.; Lee, H. W.; Lee, I. J. Org. Chem. 2000, 65, 12. (b) Lee, H. W.; Guha, A. K.; Kim, C. K.; Lee, I. J. Org. Chem. 2002, 67, 2215. (c) Adhikary, K. K.; Lee, H. W.; Lee, I. Bull. Korean Chem. Soc. 2003, 24, 1135. (d) Hoque, M. E. U.; Dey, N. K.; Guha, A. K.; Kim, C. K.; Lee, B. S.; Lee, H. W. Bull. Korean Chem. Soc. 2007, 28, 1797. (e) Adhikary, K. K.; Lumbiny, B. J.; Kim, C. K.; Lee, H. W. Bull. Korean Chem. Soc. 2008, 29, 851. (f) Lumbiny, B. J.; Adhikary, K. K.; Lee, B. S.; Lee, H. W. Bull. Korean Chem. Soc. 2008, 29, 1769. (g) Dey, N. K.; Hoque, M. E. U.; Kim, C. K.; Lee, H. W. J. Phys. Org. Chem. 2010, 23, 1022. (h) Dey, N. K.; Adhikary, K. K.; Kim, C. K.; Lee, H. W. Bull. Korean Chem. Soc. 2010, 31, 3856. (i) Dey, N. K.; Kim, C. K.; Lee, H. W. Bull. Korean Chem. Soc. 2011, 32, 709. (j) Hoque, M. E. U.; Dey, S.; Kim, C. K.; Lee, H. W. Bull. Korean Chem. Soc. 2011, 32, 1138. (k) Guha, A. K.; Hoque, M. E. U.; Lee, H. W. Bull. Korean Chem. Soc. 2011, 32, 1375. (1) Guha, A. K.; Kim, C. K.; Lee, H. W. J. Phys. Org. Chem. 2011, 24, 474.

3. Adhikary, K. K.; Lee, H. W. Bull. Korean Chem. Soc. 2011, 32, 1625 .

4. (a) Lee, I.; Kim, C. K.; Li, H. G.; Sohn, C. K.; Kim, C. K.; Lee, H. W.; Lee, B. S. J. Am. Chem. Soc. 2000, 122, 11162. (b) Han, I. S.; Kim, C. K.; Lee, H. W. Bull. Korean Chem. Soc. 2011, 32, 889.

5. (a) Ritchie, C. D. In Solute-Solvent Interactions; Coetzee, J. F., Ritchie, C. D., Eds.; Marcel Dekker: New York, 1969; Chapter 4. (b) Coetzee, J. F. Prog. Phys. Org. Chem. 1967, 4, 54. (c) Spillane, W. J.; Hogan, G.; McGrath, P.; King, J.; Brack, C. J. Chem. Soc., Perkin Trans. 2 1996, 2099. (d) Oh, H. K.; Woo, S. Y.; Shin, C. H.; Park, Y. S.; Lee, I. J. Org. Chem. 1997, 62, 5780.

6. Perrin and coworkers reported that the basicities of $\beta$-deuterated analogs of benzylamine, $\mathrm{N}, \mathrm{N}$-dimethylaniline and methylamine increase roughly by $0.02 \mathrm{p} K_{\mathrm{a}}$ units per deuterium, and that these effects are additive; (a) Perrin, C. I.; Engler, R. E. J. Phys. Chem. 1991, 95, 8431. (b) Perrin, C. I.; Ohta, B. K.; Kuperman, J. J. Am. Chem. Soc. 2003, 125, 15008. (c) Perrin, C. I.; Ohta, B. K.; Kuperman, J.; Liberman, J.; Erdelyi, M. J. Am. Chem. Soc. 2005, 127, 9641.

7. Charton, M. Prog. Phys. Org. Chem. 1987, 16, 287.

8. Hehre, W. J.; Random, L.; Schleyer, P. V. R.; Pople, J. A. Ab Initio Molecular Orbital Theory; Wiley: New York, 1986; Chapter 4.
9. Taft, R. W. Steric Effect in Organic Chemistry; Newman, M. S., Ed.; Wiley: New York, 1956; Chapter 3.

10. (a) Hengge, A. C.; Onyido, I. Curr. Org. Chem. 2005, 9, 61. (b) Omakor, J. E.; Onyido, I.; van Loon, G. W.; Buncel, E. J. Chem. Soc., Perkin Trans. 2 2001, 324. (c) Gregersen, B. A.; Lopez, X.; York, D. M. J. Am. Chem. Soc. 2003, 125, 7178. (d) Hondal, R. J.; Bruzik, K. S.; Zhao, Z.; Tsai, M. D. J. Am. Chem. Soc. 1997, 119, 5477. (e) Onyido, I.; Swierczek, K.; Purcell, J.; Hengge, A. C. J. Am. Chem. Soc. 2005, 127, 7703. (f) Holtz, K. M.; Catrina, I. E.; Hengge, A. C.; Kantrowitz, E. R. Biochemistry 2000, 39, 9451. (g) Liu, Y.; Gregersen, B. A.; Hengge, A. C.; York, D. M. Biochemistry 2006, 45, 10043. (h) Zhang, L.; Xie, D.; Xu, D.; Guo, H. J. Phys. Chem. A 2005, 109, 11295.

11. (a) Dunn, E. J.; Buncel, E. Can. J. Chem. 1989, 67, 1440. (b) Dunn, E. J.; Moir, R. Y.; Buncel, E.; Purdon, J. G.; Bannard, R. A. B. Can. J. Chem. 1990, 68, 1837. (c) Buncel, E.; Albright, K. G.; Onyido, I. Org. Biomol. Chem. 2004, 2, 601. (d) Onyido, I.; Albright, K.; Buncel, E. Org. Biomol. Chem. 2005, 3, 1468.

12. (a) Williams, A.; Naylor, R. A. J. Chem. Soc. B 1971, 1967. (b) Douglas, K. T.; Williams, A. J. Chem. Soc., Perkin Trans 2 1976, 515.

13. Until now, the anilinolysis of $O$-aryl methyl phosphonochloridothioates is the only one yielding nonlinear biphasic free energy correlations among all of the studied $\mathrm{P}=\mathrm{O}$ and $\mathrm{P}=\mathrm{S}$ systems.

14. The DKIE of $k_{\mathrm{H}} / k_{\mathrm{D}}=0.367$ for the reaction of $O$-4-cyanophenyl methyl phosphonochloridothioates with 4-chloroaniline in $\mathrm{MeCN}$ at $55.0^{\circ} \mathrm{C}$ is the smallest value, i.e., unprecedented greatest secondary inverse.

15. (a) Lee, I.; Koh, H. J.; Lee, B. S.; Lee, H. W. J. Chem. Soc., Chem. Commun. 1990, 335. (b) Lee, I. Chem. Soc. Rev. 1995, 24, 223. (c) Marlier, J. F. Acc. Chem. Res. 2001, 34, 283. (d) Westaway, K. C. Adv. Phys. Org. Chem. 2006, 41, 217. (e) Villano, S. M.; Kato, S.; Bierbaum, V. M. J. Am. Chem. Soc. 2006, 128, 736. (f) Gronert, S.; Fajin, A. E.; Wong, L. J. Am. Chem. Soc. 2007, 129, 5330.

16. (a) Poirier, R. A.; Youliang, W.; Westaway, K. C. J. Am. Chem. Soc. 1994, 116, 2526. (b) Yamata, H.; Ando, T.; Nagase, S.; Hanamusa, M.; Morokuma, K. J. Org. Chem. 1984, 49, 631. (c) Xhao, X. G.; Tucker, S. C.; Truhlar, D. G. J. Am. Chem. Soc. 1991, $113,826$.

17. The value of $k_{\mathrm{H}} / k_{\mathrm{D}}=2.10$ for the reaction of $\mathbf{3 0}$ with 4methoxyaniline in $\mathrm{MeCN}$ at $55.0^{\circ} \mathrm{C}$ is the largest one observed for the anilinolyses of $\mathrm{R}_{1} \mathrm{R}_{2} \mathrm{P}(=\mathrm{O}$ or $\mathrm{S}) \mathrm{Cl}$-type substrates. Although the primary normal DKIEs $\left(k_{\mathrm{H}} / k_{\mathrm{D}}=1.62-2.10\right)$ of $\mathbf{3 O}$ are greater than those $\left(k_{\mathrm{H}} / k_{\mathrm{D}}=1.42-1.82\right)$ of $\mathbf{4 O}$, there is no doubt that the anilinolyses of both substrates predominantly proceed through frontside nucleophilic attack.

18. This lab has cumulated data of DKIEs for the anilinolyses and benzylaminolyses of various kinds of substrates in $\mathrm{MeCN}$ and DMSO.

19. The anilinolyses of dimethyl chlorothiophosphate $\left[(\mathrm{MeO})_{2} \mathrm{P}(=\mathrm{S}) \mathrm{Cl}\right]$ $\left(k_{\mathrm{H}} / k_{\mathrm{D}}=0.95-1.1\right)$, dicyclohexyl phosphinic chloride $\left(k_{\mathrm{H}} / k_{\mathrm{D}}=0.67-\right.$ $1.05)$, and $O$-aryl methyl phosphonochloridothioates $\left[\mathrm{Me}\left(\mathrm{YC}_{6} \mathrm{H}_{4} \mathrm{O}\right)-\right.$ $\mathrm{P}(=\mathrm{S}) \mathrm{Cl}]\left(k_{\mathrm{H}} / k_{\mathrm{D}}=1.0-1.3\right.$ with the strongly basic anilines and $k_{\mathrm{H}} /$ $k_{\mathrm{D}}=0.37-0.57$ with the weakly basic anilines), and the present work simultaneously yielded both primary normal and secondary inverse DKIEs. All the other studied $\mathrm{P}=\mathrm{O}$ and $\mathrm{P}=\mathrm{S}$ substrates yielded either primary normal or secondary inverse DKIEs.

20. The reactions of $O$-aryl methyl phosphonochloridothioates with the weakly basic anilines proceed through a stepwise mechanism with a rate-limiting bond breaking.

21. Birdsall, D. J.; Slawin, A. M. Z.; Woollins, J. D. Polyhedron 2001, $20,125$. 